\title{
Krisis Nalar Fikih \\ (Pembacaan Perspektif Epistemologi Jabirian Dan Hamadian)
}

\author{
Asmuni \\ Fakultas Ilmu Agama Islam, Universitas Islam Indonesia \\ Email : asmuni@uii.ac.id
}

\begin{abstract}
Abstrak
Banyak kalangan menganggap bahwa fikih tidak lagi menjadi dirinya sendiri yang dinamis mengikuti gerak hidup umat muslim. Bahkan, ia dianggap problem utama dan menghambat kemajuan karena tidak sedikit aspek-aspek hukum yang belum dijawab oleh fikih. Sehingga tidak mengherankan jika saat ini fikih seolah-olah lumpuh karena tersandra oleh mazhab yang mengakibatkan fikih terjangkit penyakit trombosis. Tulisan ini akan membahas krisis nalar fikih dengan menggunakan bantuan model epistemologi yang diperkenalkan oleh Muhammad Abed Al-Jabiri dan Muhammad Abu Al-Qasim Haj Hamad. Melalui tulisan ini, diharapkan nalar fikih bisa kembali sehat dan mampu menjawab pertanyaan-pertanyaan baik klasik maupun kontemporer melalui perpekstif epistemologi Jabirian dan Hamadian. Perspektif Jabirian digali secara sistematis, analitis, logis melalui karya Al-Jabiri yang sangat monumental yaitu "Madkhal ila Falsafat al-'Ulum al-Aqlaniyyah". Kemudian, komposisi budaya yang membentuk nalar klasik untuk memahami nash Al-Quran hanya dapat diungkap melalui epistemologi atau filsafat ilmu yang terbarukan dan diperkaya dengan konsep-konsep keilmuan Islam. Al-Jabiri memaparkan tentang dominasi Bedouin serta pengaruhnya dalam membaca nash Al-Qur'an. Sedangkan,Haj Hamad ingin mengawal syariah Islamiyah agar tetap menyandang predikat agama yang penuh rahmah serta untuk membebaskan Al-Quran dari kepicikan dan kesempitan teologis menuju horizon universal. Sehingga apa yang dipraktikkan Al-Jabiri dan Haj Hamad dalam memaknai tasyri al-munazzal dalam menjelaskan relatifitas tasyri dikorelasikan dengan situasi dan kondisi historis, agar interpretasi itu tidak kehilangan nalar fikih.
\end{abstract}

Kata Kunci: Krisis, Nalar fikih, Epistemologi Jabirian, Epistemologi Hamadian 


\title{
Crisis Of Fiqh Reasoning (Interpreting The Perspective Of Jabirian And Hamadian Epistemology)
}

\author{
Asmuni Mth \\ Faculty of Islamic Studies, Universitas Islam Indonesia
}

\begin{abstract}
Many people believe that figh is no longer dynamic, adjusting to any changes which take place among Muslim community. Worse, figh is considered as the greatest challenge which hinders development because it has not covered various legal aspects. Therefore, it is not surprising that figh now seems to be paralyzed provided that it now suffers from serious problem. This article discusses crisis of figh reasoning using the epistemology in troduced by Muhammad Abed Al-Jabiri and Muhammad Abu AlQasim Haj Hamad. By the presence of this article, it is expected that figh could return to its healthy state and could respond to various classical and contemporary questions using the perspective of Jabirian and Hamadian epistemology. The Jabirian perspective was explored systematically, analytically, and logically using a very monumental work by Al-Jabiri, namely "Madkhalila Falsafat al-'Ulum al-Aqlaniyyah". In fact, the cultural composition which shapes classical reasoning to understand the Quran can only be explored using the latest epistemology or philosophy, combined with Islamic concepts. Al-Jabiri explained the dominance of Bedouins and their impacts in interpreting the Quran. On the other hand, Haj Hamad wanted to maintain Islamic law as a religion of mercy and to free the Quran from the narrow-mindedness of theology into universal horizon. Therefore, Al-Jabiri and Haj Hamad interpreted tasyri al-munazzal and explained the relativity of tasyri by correlating it with historical conditions, thus the interpretation will not lose figh reasoning
\end{abstract}

Keywords: Crisis, Figh Reasoning, Jabirian Epistemology, Hamadian Epistemology

\section{PENDAHULUAN}

Fikih (baca: Hukum Islam) oleh banyak kalangan dianggap menjadi problem utama dan menghambat kemajuan. Ia tidak berkembang mengikuti irama perkembangan kehidupan umat muslim. Ada yang berpendapat ketidakmampun fikih ini dimulai sejak pendudukan Mesir oleh Napo- 
leon Bonaparte. Bahkan, ada pendapat lain yang mengatakan sejak kaidah ushul dan kaidah fikih berada dalam sandra mazhab, fikih berstatus mapan, dan pintu ijtihad ditutup rapat. Aktifitas ijtihadi untuk menjawab masalahmasalah kekinian pasca kodifikasi mazhab sudah tidak independen, melainkan tergantung mazhab yang dianut para faqih (ahli fikih) dan tidak boleh keluar dari nalar analogis yang bersifat asumtif (qiyas ushuli) dan pemekaran makna nash dalam bingkai kaidah-kaidah bahasa Arab sebagai bahasa komunikasi, bukan kaidah bahasa Al-Qur'an sebagai bahasa Arab yang digunakan oleh Tuhan. Bahasa Arab sebagai bahasa komunikasi, dengan bahasa Al-Qur'an sebagai bahasa Tuhan memiliki sejumlah perbedaan baik dari aspek gramatikal maupun pemaknaan. Dilihat dari aspek teoritis, hal ini disinyalir berkonstribusi membuat krisis nalar fikih.

Adapun dari sisi implementasi fikih dalam kehidupan, keberadaan fikih hanya mengawal kehidupan muslim dari aspek-aspek tertentu dalam wilayah hukum keluarga. Sedangkan wilayah lain seperti sosial politik dan ekonomi bahkan hukum keluarga tertentu sekalipun, fikih tidak mampu memberikan konstribusi. Mungkin tidak terlalu salah kalau kita mengatakan bahwa umat muslim lebih nyaman hidup di luar ketentuan fikih-nya. Salah satu penyebabnya, fikih dianggap tidak mampu beradaptasi dengan perubahan. Hal ini paradok dengan pernyataan sejumlah orientalis yang menyebut bahwa hadharah islamiyyah adalah hadharah qanun, ${ }^{1}$ yang menggambarkan masa lampau di mana fikih selalu mengawal dan menjadi pedoman dalam kehidupan muslim.

Untuk menggambarkan krisis fikih sebagai fenomena faktual, mungkin tepat kalau kita mengatakan bahwa fikih sedang terjangkit penyakit trombosis $^{2}$. Krisis nalar fikih dengan berbagai manifestasi dan paradoksinya sering menjadi topik kritik para ilmuan studi Islam, bahkan oleh sejumlah orien-

1 Istilah tersebut parallel dengan istilah hadharat al-'amal (peradaban kerja) bagi masyarakat Tiongkok atau hadharah al-falsafah (peradaban filsafat) bagi bangsa Yunani Eropa.

2 Biasanya beberapa penulis menggunakan istilah al-insidad, dipinjam dari turas Syi'ah. Istilah ini dapat diartikan dengan penyakit trombosis untuk menggambarkan krisis faktual baik teoritis maupun praksis yang terjadi pada fikih. Teoretis dalam arti nalar fikih diharapkan mampu memenuhi keinginan ambisius untuk meraih kemajuan seperti teori-teori ekonomi, politik, pendidikan dan seni...dan seterusnya. Hal ini belum sepenuhnya terwujud. Sedangkan praksis, fikih harus fungsionil mengawal kemajuan umat Islam dalam berbagai bidang kehidupan. Ini pun masih jauh dari harapan. Antara nalar fikih dengan kebutuhan dan keinginan ambisius tidak sejalan. Sampai saat ini kebutuhan kekinian akan fikih masih mengharapkan stok yang tersimpan dalam lumbung fikih mazhab. 
talis yang semula menyebut peradaban Islam sebagai hadharah qanun ${ }^{3}$ yang selalu mengawali sekaligus menjadi pedoman kehidupan muslim. Realitas kehidupan masyarakat muslim menunjukkan sebaliknya. Fikih yang sejak awal telah mengambil posisi qanun tersebut, di era sekarang, sudah jauh dari makna-makna ini.

Sumber krisis nalar fikih disinyalir dari suatu fakta bahwa nalar Arab dibangun berdasarkan pemikiran-pemikiran sebelumnya yang berkembang sebelum Islam hadir. Masyarakat Arab memiliki prakonsepsi yang membingkai proses pemahaman terhadap nash-nash pokok. Prakonsepsi ini kemudian menjadi cikal bakal benih krisis yang kemudian dalam perjalanannya membesar dan menghalangi nalar fikih bahkan nalar ilmu pengetahuan secara keseluruhan. ${ }^{4}$

Risalah Muhammadiyah telah melakukan revolusi terhadap budaya dan pemikiran Arab pada era Jahiliyah, namun beberapa karakter sosiologis dan psikologis Arab yang kurang terpuji belum sepenuhnya hilang. Minimal ada dua fakta menunjukkan hal tersebut. Pertama, masyarakat Arab belum mampu membangun kehidupan yang rukun (al-salam) dan selalu saling mencurigai. Sikap bermusuhan dan berperang (iqtital) antara satu suku dengan suku yang lain yang sering terjadi di era Jahilyah kadang-kadang masih mewarnai kehidupan mereka sampai sekarang. Kekasaran dan kekerasan hati masyarakat Bedouin (khusyunah badawiyah) disinyalir mewarnai rumusan fikih.

Kedua, risalah Islamiyah telah mendorong mereka melakukan migrasi psikologis dari kehidupan Bedouin (badawah) menuju kehidupan yang berperadaban modern (tahadh-dhur). Kehidupan modern ini dapat dipastikan sudah diraih oleh bangsa Arab. Mereka bersama-sama kaum muslim yang lain berkonstribusi banyak dalam membangun peradaban Islam. Tetapi permasalahannya, dalam memahami nash-nash pokok mereka masih menggunakan struktur bahasa Bedouin Jahiliyah. Tidak melihat bahasa Al-Qur'an

3 Istilah tersebut parallel dengan istilah hadharat al-'amal (peradaban kerja) bagi masyarakat Tiongkok atau hadharah al-falsafah (peradaban filsafat) bagi bangsa Yunani atau Eropa.

4 Dicky Wirianto, "WACANA REKONSTRUKSI TURAS (TRADISI) ARAB Menurut Muhammad Abed al-Jabiri Dan Hasan Hanafi," t.t.; Muhamad Rofiq, "Arab Political Reasoning: Muhammad Abid al-Jabiri's Contribution for Understanding Crisis of Politics in the Arab World," Indonesian Journal of Islam and Muslim Societies 7, no. 1 (1 Juni 2017): 55-76, https:/ / doi.org/10.18326/ijims.v7i1.55-76. 
sebagai bahasa Tuhan yang memiliki kapasitas dan dimensi yang berbeda dengan bahasa komunikasi. ${ }^{5}$

Fakta lain menunjukkan bahwa kaidah-kaidah ijtihad yang ada tidak mampu meminimalkan silang pendapat. Kontradiksi-kontradiksi selalu bermunculan dalam ranah fikih. Artinya, nalar fikih tidak mampu meletakkan asas-asas teoritis yang mempersatukan umat. Sikap saling menyalahkan, bahkan saling mencemoohkan bersumber dari fikih. Fikih golongan tertentu menjelma menjadi "fikih narsis", yang selalu membenarkan diri dan menyalahkan golongan lain. Hal ini membuktikan bahwa nalar fikih sedang terjangkit penyakit lain yaitu penyakir inersia atau ketidak sanggupan fikih untuk bergerak melihat perubahan (qushur zati). Inilah yang menghalanginya untuk melakukan penalaran secara benar. Inersia ini kemudian melahirkan kesalahan-kesalahan pada struktur subtantif dalam nalar Islam. Ekspresinya yang paling jelas adalah terjadinya banyak pertentanga pada deep structure sehingga mengacaukan dalam menentukan standar prioritas, dan lemahnya kemampuan analisis dan sempitnya cakrawala nalar analogis (qiyas).

Krisis nalar dan berkelindannya beragam pendapat dalam fikih jika dihubungkan dengan makna fikih, ternyata tidak saling berkorelasi. Keberadaan fikih, sudah sejatinya dapat menjadi sumber inspirasi dan mendorong nalar revisionis terhadap berbagai ilmu pengetahuan. Menjawab berbagai problem dan mencari akar permasalahan dalam berbagai aspek dan level kehidupan. Secara fonologi, kata fikih berada dalam urutan tangga suara: الفاء suara yang datang dari permulaan mulut, القاف suara yang datang dari tengah kerongkongan dan الهاء suara yang datang dari ujung akhir tenggorokan. Konstribusi interpretatif dari proses ini bergerak dari permukaan (permulaan mulut) ke dalam (ujung tenggorokan) sejalan dengan makna leksikal dari kata fikih. Fikih adalah "pemahaman yang dalam" artinya proses intelektualitas bergerak dari eksterior (untuk memahami permasalahan yang terlihat di permukaan) sampai ke interiornya (memahami permasalahan yang bersemayam di bagian dalam dan tidak terlihat). Pemak-

5 Ahmad Amin, Fajru al-Islam (Beirut: Dar al-Kitab al-'Arabi, 1969); Muhammad Âbid al-Jâbirî, Madkhal Ila Falsafah al-'Ulum, vol. 1 (Beirut: Markaz Dirâsât al-Wihdah al-'Arabiyah, 1988); Ahmad Abdurrazak Al Khani, Mukhtashar al bidayah wa an-nihayah sejarah awal mula penciptaan, kisah para Nabi, kisah umat-umat terdahulu, sejarah Nabi SAW dan Khulafa'Rasyidun, daulah Umawiyah dan Abasiyah, hingga peristiwa tahun 768 H (Jakarta: Pustakaazzam, 2013). 
naan orientatif ini identik dengan arah pemaknaan kata filsafat, karena filsafat sendiri bermakna menggali secara mendalam prinsip-prinsip berpikir untuk menembus akar persoalan. ${ }^{6}$ Pemaknaan filsafat seperti ini merupakan manifestasi yang jelas dan paling logik. Jika kata fikih diparalelkan dengan kata filsafat menunjukkan hal yang paradoksial, karena realitas nalar Islam dan sejarahnya adalah nalar yang sedikit banyak menjauh dari filsafat. ${ }^{7}$

Dari uraian singkat di atas beragam permasalahan dapat teridentifikasi. Mislanya fikih dalam pengembangannya tidak boleh berjalan sendirian. Ia harus berdampingan dengan filsafat fikih. Demikian pula penerapan fikih ia membutuhkan ilmu lain seperti sosiologi dan antropologi. Sedangkan nalar fikih harus berangkat dari nash-nash pokok dengan mengkaji berbagai perubahan sehingga produk fikih mampu beradaptasi dengan perubahan tersebut. Akan tetapi fakta menunjukkan sebaliknya bahwa saat ini fikih tidak mampu bergerak untuk beradaptasi dengan perubahan.

Tulisan ini juga bertujuan untuk mengetahui bahwa fikih itu selalu berkembang dari zaman ke zaman, apalagi kaitannya dengan hukum yang sangat luas, terkait prilaku manusia dan lain sebagainya. Selain itu fikih juga membutuhkan filsafat ilmu agar fikih tersebut dapat berkembang menyesuaikan zamannya. Jenis penelitian ini adalah penelitian dasar dengan pendekatan kualitatif. ${ }^{8}$ Penelitian dasar dalam hal ini akan digunakan sebagai acuan untuk penulisan karya ini. Penelitian juga merupakan penelitian Studi Pustaka. Sedangkan sumber data yang digunakan adalah data sekunder dengan pendekatan kualitatif dalam hal ini mengakaji tentang krisis nalar fikh.

6 Syamsul Rizal, “Epistemologi Filsafat Islam Dalam Kerangka Pemikiran Abid Al-Jabiri,” AtTafkir 1, no. 1 (2014): 100 - 130-100 - 130.

7 Muhammad Anwar Firdausy, "Filsafat Mohammad Abid Al Jabiri Dan Relevansinya Dalam Pemikiran Islam Kontemporer," t.t.; Wahyudi Wahyudi dan Muhammad Zaini, "Characteristics And Paradigm Of Sufi Tafsīr In 'Abid Al-Jabiri Epistemology Perspective," Kalam 12, no. 1 (3 Juli 2018): 159-78, https:// doi.org/10.24042/klm.v12i1.2152.

8 A. Muri Yusuf, Metode penelitian : kuantitatif, kualitatif, dan penelitian gabungan (Kencana, 2015); Matthew B. Miles dan A. Michael Huberman, Analisis Data Kualitatif: Buku Sumber Tentang Metode-metode Baru (UI Press, 2009), https:/ / openlibrary.telkomuniversity.ac.id/pustaka/9207/analisis-data-kualitatifbuku-sumber-tentang-metode-metode-baru.html. 


\section{EPISTEMOLOGI: KONSEP DAN KEGUNAAN}

Baik Al-Jabiri maupun Haj Hamad mendefinisikan epistemologi sejalan dengan tujuan-tujuan proyek mereka. Al-Jabiri sebagaimana yang sudah kita kenal mengusung proyek kritik dan melakukan dekonstruksi nalar Arab. Sedangkan proyek Haj Hamad tercermin dalam pembentukan epistemologi kosmopolitan yang akan menjadi alternatif pengganti peradaban Barat modern yang universal. Berdasarkan hal ini, maka kita harus mengkorelasikan tujuan proyek secara total dengan konsep epistemologi mereka. Uraian berikut ini akan difokuskan pada al-Jabiri dan Haj Hamad dengan volume uraian yang lebih banyak pada tokoh yang kedua.

\section{Epistemologi Jabirian}

Al-Jabiri menulis buku yang berjudul 'Madkhal ila Falsafat al-'Ulum al'Aqlaniyyah". Dari judulnya, karya ini tidak lebih dari buku ajar yang berada di luar bingkai proyek Kritik Nalar Arab. Akan tetapi dari dua karyanya yang lain yang berisi tentang konstruksi proyeknya yaitu Takwin al-`Aql al'Arabi dan Bunyah al-`Aql al-`Arabi kita dapat memahami hubungan yang kokoh antara epistemologi dengan proyek kritik yang diusungnya. Bagi alJabiri epistemologi adalah ilmu tentang pengetahuan atau 'ilm al-ma'rifah. Di dalam al-ma'rifah tercermin hubungan antara orang yang mengetahui (al-zat al-'arifah) dan obyek yang akan diketahui (al-maudhu' al-murad ma'rifatuhu). Dengan demikian, epistemologi adalah ilmu yang fokus memperhatikan studi tentang hubungan ini"9 Artinya, epistemologi adalah ilmu yang mementingkan atau memperhatikan studi tentang hubungan timbal balik antara seseorang yang melakukan kajian (al-zat) dengan obyek yang dikaji dan akan diketahui (al-maudhu') dari sudut pengaruh obyek terhadap subyek dan perbuatan subyek terhadap obyek. Dari hubungan timbal balik (reciprocal) ini maka terbentuklah evolusi sejarah. Sehubungan dengan ini, al-Jabiri mengatakan:" pengaruh yang timbal balik dan berkesinambungan antara subyek dan obyek ini menjadikan hubungan anatara keduanya (selanjutnya hubungan dengan ilmu penegtahuan) meruapakan proses historical yang

9 Muhammad Âbid al-Jâbirî, Madkhal Ila Falsafah al-‘Ulum, vol. 1 (Beirut: Markaz Dirâsât al-Wihdah al-'Arabiyah, 1988), hal 47. 
berjalinan. ${ }^{10}$ Di sini al-Jabiri menjadikan sejarah sebagai unsur tambahan dalam definisi epistemologi. Maka dengan demikian, epistemologi mempelajari tentang hubungan dan selanjutnya mempelajari tentang struktur nalar (bunyah), demikian pula perkembangan dan pembentukan hubungan antara subyek abyek. Artinya, sejarah dan tujuan di sini bukan kronologis sesuai penelusuran jejak bagi efektifitas pemikiran sebagai jalan untuk mewujudkan fasilitas yang mengungkap sebagiannya dan menyisakan yang lain.

Setelah al-Jabiri menyebutkan bahwa unsur berupa hubungan dan sejarah, ia justru menambahkan unsur lain lagi yaitu kritik. Hal ini dapat kita pastikan karena ia menyebutkan "dengan demikian, kita mengatakan bahwa epistemologi, sesungguhnya mempelajari dan mengkritik kesadaran manusia tentang alam -termasuk di dalamnya manusia itu sendiri- kesadaran yang membentuk kemungkinan obyektifitas yang lebih besar". ${ }^{11}$ Artinya kritik merambat sampai kepada pengetahuan ilmiah dan metode yang membentuk konsepsi kita tentang alam.

Dengan demikian, epistemologi menurut al-Jabiri adalah studi kritis dan historis terhadap hubungan yang terjadi antara subyek yang mengetahui (al-zat al-'arifah) dan obyek yang dituju atau obyek yang dikehendaki untuk diketahui. Epistemologi ini nampak dalam studinya tentang turas Islam secara umum melaui karyanya Takwin al-`Aql al-`Arabi yaitu studi kritis terhadap hubungan melalui sejarah pembentukan nalar Arab, kemudian melakukan kritik dan mengoreksi hubungan ini melalui karyanya Bunyat al'Aql al-'Arabi. Adapun karya-karyanya yang lain hanya sebagai pelengkap dua agenda proyek ilmiahnya yang besar.

\section{Epistemologi Hamadian}

Sebelum kita masuk pada uraian tentang epistemologi Hamadian, sangat bijak kalau kita lebih awal memaparkan dua tantangan yang dihadapi umat muslim yang menjadi bagian dalam pembentukan epistemologinya. Menurut pengakuan Haj Hamad banyak tantangan yang berhubungan dengan konsep kita tentang tasyri'at al-islamiyah dari satu sisi, dan pengaplikasi-

10 Muhammad Âbid al-Jâbirî, At-Turats wa al-Hadatsah: Dirasah wa Munaqasyah, vol. 1 (Beirut: Markaz Dirâsât al-Wihdah al-'Arabiyah, 1991); al-Jâbirî, Madkhal Ila Falsafah al-'Ulum.

11 al-Jâbirî, hlm 48 
annya di tengah perubahan kualitatif bagi masyarakat muslim modern pada sisi lain. ${ }^{12}$

Dari sejumlah tantangan-tantangan itu, ada dua tantangan yang dikategorisasi sebagai tantangan yang fundamental. Pertama, dominasi peradaban Barat terhadap berbagai eksperimen manusia modern. Peradaban Barat ini melakukan intervensi secara perlahan tapi pasti sejak pertengahan abad ke XIX. Permasalahan dalam konteks ini bahwa peradaban Barat memiliki karakteristik (positivistik). Ia memisahkan teologi dan nalar metafisis. Doktrin positivistik mengeluarkan sejumlah konsep-konsep kemoderenan yang (mendekonstruksi berbagai postulat) yang berkaitan dengan al-kaun dan alinsan yang pada akhirnya berakhir dengan liberalisme. Kemudian posmodernisme berakhir pada dekonstruksi identitas (tafkik al-zat) kemanusiaan itu sendiri melalui pemahaman (konsepsi) yang negatif pada prinsip-prinsip alshairurah (proses menjadi), al-tahawwul (transformasi), al-nisbiyah (relatifitas) dan al-ihtimaliyah (probabilisme). Bahayanya di sini terletak antara dekonstruksi postulat dengan dekonstruksi identitas manusia dapat merobek nilai-nilai yang berkaitan dengan hukum keluarga, agama, bangunan etika publik berdasarkan tasyri'at diniyah (hukum-hukum keagamaan). Identitas individu yang liberalistik kemudian menyingkirkan bahkan menjauhkan semua nilai atas nama postulat tradisional yang sepenuhnya sudah didekonstruksi. Di sinilah kemudian tasyri'at diniyah dipandang sebagai sistem yang bertentangan dengan nilai-nilai kemoderenan dan liberalisasi manusia moderen yang sesekali melakukan kritik atas konsep-konsep yang mendasari tasyri' dari satu sisi seperti kebebasan seks misalnya, dan kekhususan hukuman seperti hukuman dera, rajam atau potong tangan bagi pencuri maupun hukuman lainnya.

Tantangan kedua, jika sistem peradaban Barat yang mengeluarkan konsep-konsep ini bertentangan dengan sistem peradaban islami, hal ini bukan berarti masyarakat muslim tidak bergabung ke dalamnya atau tidak akan terkena pengaruhnya yang positif maupun yang negatif. Khususnya karena eksprimen muslim baik fikih maupun perundang-undangan berdasarkan ijtihad-ijtihad komposisional dalam situasi dan kondisi masyarakat

12 Abû al-Qâsim Hâj Hamad, al-Muhaddadat al-Qur'aniyyah Li-Shiyagati al-Nash al-Tasyri'i baina al-Muthlaq wa al-Nisbi wa baina al-Syir'ah wa al-Minhaj, vol. 1 (Beirut: Dâr al-Sâqî, 1999), hlm 193-204. 
pedalaman (badawiyah), pengembala dan petani yang memiliki stereotype tradisional baik dalam hubungan sosial, ekonomi, sarana-sarana produksi dan alat-alatnya. Di era modern ini, umat muslim benar-benar menghadapi perubahan-perubahan kualitatif. Hal ini dapat dibuktikan dengan berbagai seruan pemikir muslim secara terus menerus untuk melakukan ijtihad, tajdid (modernisasi) dan tajaddud (rekonstruksi), dan usaha-usaha pemikiran muslim yang berkesinambungan semenjak satu setengah abad untuk menemukan kembali agama. Umat muslim pun berdialog dengan liberalisme dari satu sisi dan sosialisme dari sisi lain. Pada posisi ini muslim kadang kala melakukan adaptasi dengan Barat dalam konteks muqarabah (harmonisasi konseptual Barat dan Islam), meskipun juga tidak jarang melakukan suatu penolakan dalam konteks muqaranah (perbandingan antara sistem Barat dan Islam dengan mengunggulkan Islam secara mutlak). Mereka yang menolak sering dikelompokkan dengan komunitas salafiyyun atau ushuliyun, juga dinamai ishlahiyyun atau 'ashriyyun. Apa pun penamaan yang diberikan kepada mereka, semuanya menjadi bukti betapa dampak dari intervensi peradaban Barat dan akutnya krisis di tengah kita.

Kedua tantangan ini satu pun tidak ada yang meminta fatwa dari AlQur'an. Interaksinya dengan nash-nash Al-Qur'an sebatas menggunakannya untuk istisyhad dalam rangka memperkuat sikap dan orientasi mereka di tengah pergulatan atau konflik ini. Artinya nash-nash Al-Qur'an hanya digunakan untuk menjustifikasi dengan cara yang semberono. Nash-nash Al-Qur'an tersebut, kata Haj Hamad, dalam berbagai kesempatan digunakan untuk memapankan pemahaman manusia dan praktik historis tasyri'at Al-Qur'an. Hal yang sama juga dilakukan terhadap Sunnah yaitu mengokohkan sawabit tasyri'iyah. Semua pendapat di luar ini dianggap keluar dari al-Kitab, Sunnah dan ijma' atau sering disebut "modernisasi yang direkayasa" dan tidak berdasar. Seperti diketahui bahwa usaha-usaha takhfif yang menjadi acuan tasyri'at menunjukkan ada upaya untuk meninggalkan dan atau melampaui makna literasi nash tasyri'.

Haj Hamad tidak bermaksud melakukan kritik, tidak terhadap kaum literasi (ushuli atau salafi) dan tidak pula kepada para pengusung modernisasi. Akan tetapi ia mengemukakan suatu pertanyaan akumulatif seputar sikap Al-Qur'an itu sendiri terhadap problem ini. Apakah kita menggugurkan 
tasyri'at ini karena trend kekinian didominasi oleh positivistik liberalitik yang tidak menerima tasyri'at Al-Qur'an, ataukah kita tetap mempertahankannya meskipun terjadi perubahan dan pengaruhnya pada masyarakat muslim.

Berangkat dari tantangan yang bermuara pada alineasi yang dilakukan oleh positivistik dan teologistik tersebut, Haj Hamad mendefinisikan epistemologi sebagai upaya mengeluarkan kita dari ruang lingkup filsafat positivistic dan Marxism dan membebaskan nalar dari alienasi atau isolasi teologis, dan dalam waktu yang bersamaan Haj Hamad mengintegrasikan epistemologi dengan filsafat ilmu yang berusaha memperluas ruang lingkupnya secara keilmuan dari positivistic kepada universalistic.

Dari paradigma tersebut Haj Hamad mendefinisikan epistemologi atau filsafat ilmu dengan "filsafat pengetahuan ilmiah, sesungguhnya merupakan filsafat yang terbuka, dan merupakan kesadaran berpikir itu sendiri, membentuk eksistensinya melalui pengungkapan yang majhul (tidak diketahui) dan menelitinya pada realitas..."13 Filsafat ilmu berkembang bersamaan dengan perkembangan pengetahuan ilmiah secara terbuka, tidak mungkin mereduksinya pada dimensi positivistic yang sempit, melainkan harus melampauinya menuju horizon universal (afaq al-kauniyyah). Artinya, epistemologi harus bekerja melakukan konstruksi secara berkesinambungan untuk produk-produk keilmuan dengan cara melampaui semua rintanganrintangan ideologis seperti yang tercermin pada Marxism dan Positivistic. Upaya untuk melampaui semua rintangan tersebut diperkuat oleh produkproduk keilmuan kontemporer melalui penafian kepastian mutlak (absolute) dan munculnya relativitas dan melebarnya alam menuju macrophysics (al-lamutanahi fi al-kibar) dan microphysics (al-lamutanahi fi al-sigar).

Karena itu, epistemologi menurut Haj Hamad adalah proses penyelidikan, penelitian yang bersifat terbuka mengarah menuju universalitas dengan melampaui rintangan-rintangan yang bersifat positivistic dari sisi pembentukannya dalam konteks pemikiran Barat. Sedangkan dari sisi dunia Islam, epistemologi adalah untuk membebaskan Al-Qur'an dari kepicikan dan kesempitan teologis menuju horizon universal. Hal ini sejalan dengan

13 Abû al-Qâsim Hâj Hamad, al-'Âlamîyah al-Islâmîyah al-Sânîyah: Jadalîyat al-Gaib wa al-Insân wa al-Țabî'ah, Taqdîm wa Murâja'ah Muhammad al-'Ânî, (Beirut: Dâr al-Sâqî̀, 2012M), hlm 243. 
keberadaan Al-Qur'an sebagai kitab yang parallel dengan alam. Dari konsepsi epistemologis Hamadian dapat dipahami bahwa epistemologi sebagai petunjuk konstruksi pengetahuan ilmiah universal yang dicirikhususkan dengan spirit kritis.

\section{KRISIS NALAR FIKIH MENURUT KONSEPSI EPISTEMOLOGIS}

Apabila epistemologi sebagai pintu masuk dalam membaca turas Islam pada umumnya dan nalar fikih khususnya, maka mau tidak mau kita melihat sejauh mana efektifitasnya dalam mengungkap faktor-faktor yang menyebabkan krisis yang melanda nalar fikih. Krisis ini tidak mungkin diungkap oleh para fuqaha' (ahli fikih). Karena mereka sendiri bagian dari lingkaran krisis, bahkan metode dan produk nalar mereka adalah menjadi tempat krisis. Orang-orang yang mampu melihat krisis ini secara obyektif adalah mereka yang tidak terkait dengan nalar fikih, tetapi memiliki kepedulian pada nalar fikih atau bahkan nalar dan mekanisme dalam memproduksi keilmuan Islam. Mereka ini adalah para epistimolog.

Harus disadari bahwa krisis fikih tidak hanya berkaitan dengan mekanisme produksi fikih dan implementasinya di tengah masyarakat. Akan tetapi krisis yang melanda fikih jauh lebih dalam karena berhubungan dengan subyek atau orang (al-zat) sebagai aktor yang berupaya untuk memahami nash-nash pokok (Al-Qur'an dan As-Sunnah). Dan juga dalam waktu yang bersamaan krisis ini melakukan kodifikasi terhadap hadis dan menisbatkannya kepada Rasulullah. Jika dilihat dari sisi ini, gerakan revisionis terhadap mekanisme nalar fikih jauh lebih penting dari pada menyelidiki implementasi fikih di tengah kehidupan umat muslim. Disinilah letak relevansi epistemologi al-Jabiri dan Haj Hamad dalam melakukan analisis terhadap krisis nalar fikih sebagai ikhtiyar untuk mencari akar permasalahannya

\section{Jabiri dan Tesis al-Badawi sebagai Musyarri'}

Metode yang digunakan Al-Jabiri dalam membaca turas dapat diketahui melalui pernyataannya tentang epistem (nizam ma'rifi), al-Jabiri mengatakan: sebagai prinsip-prinsip, kaidah-kaidah, konsep-konsep yang disediakan oleh budaya tertentu untuk orang-orang yang berada di dalam budaya tersebut. Dalam konteks kritik nalar teoritis Arab, dapat ditegaskan bahwa 
akal sebagaimana yang disebutkan fungsinya adalah memberikan panduan dan arah bagi orang-orang yang hidup di dalam budaya Arab dalam memproduksi dan menghasilkan pengetahuan. Atau mengikuti istilah al-Jâbirî adalah akal sebagai episteme. ${ }^{14}$

Episteme (an-nidzâm al-ma'rifi) adalah perangkat konseptual yang digunakan oleh al-Jâbirî untuk memberikan batasan lain terhadap obyek studinya yaitu nalar teoritis Arab. Al-Jâbirî mendefinisikan episteme sebagai, "konsep-konsep, prinsip-prinsip dan proses-proses yang memberikan struktur bawah sadar kepada pengetahuan dalam periode sejarah tertentu." Definisi ini kemudian dipertegas oleh al-Jâbirî dengan menyebutkan bahwa sistem pengetahuan dalam setiap budaya adalah struktur bawah sadarnya. ${ }^{15}$

Konsep ini mirip dengan konsep episteme Michel Foucault, ${ }^{16}$ filsuf Perancis kontemporer yang melihat episteme sebagai pengandaian-pengandaian, prinsip-prinsip, syarat-syarat kemung-kinan dan cara-cara pendekatan tertentu yang ada pada tiap-tiap zaman. Semua pengandaian itu membentuk sistem yang teguh dan tidak disadari dengan jelas oleh orang-orang yang berada dalam periode tersebut, akan tetapi secara tersembunyi dan melalui mekanisme bawah sadar menentukan dan mengarahkan pemikiran, pengamatan dan pembicaraan mereka. Setiap zaman mempunyai suatu episteme tertentu yang merupakan landasan atau fundamen epistemologis bagi zaman itu. Episteme ini juga yang menentukan cara-cara ilmu pengetahuan akan dijalankan.

Jika mengikuti definisi dan batasan yang diberikan oleh al-Jâbirî terhadap sistem pengetahuan, nampak jelas bahwa konsep episteme ini juga sangat terkait dengan budaya karena ia melihat hubungan yang sangat erat antara episteme dengan budaya. Lebih jauh, hubungan ini menurutnya, mengambil dua bentuk yaitu bahwa episteme di satu sisi dibentuk di dalam budaya tertentu dan di sisi lain pada saat yang sama juga dipraktekkan dalam budaya

14 Muhammad Âbid al-Jâbirî, Bunyah al-'Aql al-'Arabî, Dirâsah Tahlîliyah Naqdiyah li Nadzm alMa'rifah al-'Arabiyah, vol. 3 (Beirut: Markaz Dirâsât al-Wihdah al-'Arabiyah, 1990), hlm 37.

15 al-Jâbirî, Bunyah al-'Aql al-'Arabî, Dirâsah Tahlîliyah Naqdiyah li Nadzm al-Ma'rifah al-'Arabiyah, hlm 38 .

16 Muhammad Âbid al-Jâbirî, Al-'Aql asy-Syiyâsî al-Arabî, Muhaddadâtuhu wa Tajalliyâtuhu, vol. 2 (Beirut: Markaz Dirâsât al-Wihdah al-'Arabiyah, 1991), hlm 55 Al-Jabiri mengakui jika konsep ini terilhami oleh Michel Foucault dalam memberikan definisi dan batasan mengenai sistem pengetahuan akan tetapi ia mengklaim tidak mengikuti secara membabi buta terhadap Foucault, melainkan hanya mengambil konsep-konsepnya yang disesuaikan dengan obyeknya yang khas yaitu budaya Arab. 
tertentu. Dalam konteks studi al-Jabiri, episteme yang dimaksudkan adalah sesuatu yang dibentuk dan dipraktekkan di dalam budaya Arab-Islam.

Signifikasi dari konsep episteme ini bagi al-Jabiri adalah karena ia dapat memberikan justifikasi baginya dalam melakukan kritik nalar teoritis Arab, yaitu untuk membebaskan masyarakat Arab-Islam dari kendali "sistem pengetahuan lama" dengan membongkar dan menyadarkan mereka bagaimana sistem tersebut dibentuk dan bagaimana sistem tersebut bekerja dalam mengendalikan pemikiran mereka. Ini sejalan dengan konsep kritik al-Jabiri yang bercorak Freudian.

Dari pemaparan tersebut, al-Jabiri menetapkan tiga unsur pokok dalam definisinya tentang episteme yaitu prinsip-prinsip, prosedur-prosedur dan historisitas (tarikhiyah) dan terakhir adalah struktur di bawah sadar. Artinya, metode al-Jabiri tidak mengarah kepada kontens (madhomin), melainkan mengarah kepada prinsip dan prosedur yang memperoduksi konten-konten tersebut yang menyatu dalam batas-batas historis yang terbingkai dalam budaya Arab Jahiliyah. Dan yang terakhir ini, bekerja secara tidak sadar dalam membentuk pengetahuan yang dibangun di dalam dunia arab dan Islam.

Bagi al-Jabiri kebudayaan Arab senantiasa berafiliasi kepada masa Jahiliyah. Dalam konteks ini ia mengatakan :"Banyak sesuatu yang tidak berubah dalam kebudayaan Arab sejak masa Jahiliyah sampai sekarang, yang dalam keseluruhannya membentuk sawabit (aspek-aspek permanent) dalam kebudayaan ini, dan selanjutnya membentuk struktur nalar yang berafiliasi kepadanya: nalar arab" ${ }^{17}$ Akan tetapi bagaimana budaya jahiliyah masih tersisa dan mengakar dalam ketidaksadaran Arab, padahal Islam datang untuk mengeleminasi asas-asas budaya Jahiliyah?

Disini Al-Jabiri kembali kepada era kodifikasi dalam kurun waktu sejak abad II sampai dengan IV Hijriyyah, terutama kodifikasi bahasa Arab dan metode kodifikasinya. Keduanya menentukan sistem pengetahuan bagi nalar arab dimana Khalil al-Farahidi melakukan kodifikasi bahasa arab tidak bersandar pada bahasa Al-Qur'an yang mengandung potensi dan kemampuan semantik, melainkan bersandar pada bahasa Bedouin (al-badiyah)

17 al-Jâbirî, Bunyah al-'Aql al-'Arabî, Dirâsah Tahlîliyah Naqdiyah li Nadzm al-Ma'rifah al-'Arabiyah, hlm 39. 
yang keberadaannya sama dengan muatan pemikiran era Jahiliyah. Artinya ia senantiasa memiliki visi kosmik yang sama. Dari sini, sama artinya dengan bahwa kita kembali kepada era jahiliyah dari titk tolak yang baru dengan konsistensi-konsistensinya (al-sawabit). Kembali ke era Jahiliyah ini dibuktikan oleh mekanisme kodifikasi (al-jam'u) yang dilakukan berdasarkan qiyas terhadap contoh (fakta-fakta) sebelumnya. Artinya qiyas bahasa dilakukan berdasarkan bahasa arab Bedouin yang kemudian dijadikan referensi, bukan Al-Qur'an al-Karim.

Dengan demikian, Bedouin (badawi) kemudian menjadi musyarri' (pembuat hukum). Atau seperti dikatakan Al-Jabiri Bedouin ini bearalih menjadi ustaz bagi para ulama dalam menyelesaikan berbagai sengketa dan perselisihan" ${ }^{18}$ Di sinilah terjebaknya nalar fikih arab. Ia membaca dan memahami Al-Qur'an, mengumpulkan hadis dan menentukan hukum-hukum syariah, akan tetapi tidak sesuai dengan logika Al-Qur'an dalam mengkonsepsikan alam, melainkan sejalan dengan logika Bedouin dan wataknya yang kasar dan keras. Tempat-tempat krisis ini sangat nampak ketika al-Jabiri menyatakan bahwa bahasa arab sebagai bahasa yang perceptible (hissiyah). Kemampuannya terbatas pada hal-hal yang bersifat konkrit dan indrawi (al-idrak al-hissiyah). Sedangkan kandungan makna-makna metafisika di dalamnya sangat miskin. Dan keberadaannya sebagai bahasa yang ahistoris, tidak mampu mendiskripsikan perubahan dan perkembangan. Sehubungan dengan ini al-Jabiri mengatakan:" ketergantungan para compiler bahasa (jami' al-lugah) pada kekerasan dan kekasaran Bedouin sebagai alat ukur (miqyas) menjadikan bahasa Arab kehilangan banyak kata-kata dan konsep-konsep baru yang ada di dalam Al-Qur'an dan al-hadis"19. Makna ini bahwa para compiler bahasa arab melenyapkan banyak makna (madlulat) yang dimasukkan Al-Qur'an ke dalam bahasa Arab. Hal ini merupakan unsur yang paling berbahaya. Di sinilah sumber dari semua krisis nalar fikih yang bersemayam dalam paradok (mufaraqah) antara karakteristik bahasa Al-Qur'an yang

18 Habib Qasim Jabir, , al-Islam Baina al-Badawah wa al-Hadharah, Beirut: Dar al-Kutub Al-'Ilmiyah, 2002. (Beirut: Dar al-Kutub Al-'Ilmiyah, 2002); Muhammad Âbid al-Jâbirî, Hafriyât fî adz-Zhâkirah min Ba'id (Beirut: Markaz Dirâsât al-Wihdah al-'Arabiyah, 1997); Muhammad Âbid al-Jâbirî, Isykaliyah al-Fikr al-'Arabi al-Mu'ashir, vol. 1 (Beirut: Markaz Dirâsât al-Wihdah al-'Arabiyah, 1994).

19 al-Jâbirî, Bunyah al-'Aql al-'Arabî, Dirâsah Tahlîliyah Naqdiyah li Nadzm al-Ma'rifah al-'Arabiyah, hlm 87. 
mengekspresikan al-gaib dan karakter bahasa arab Bedouin yang percebtible (hissiyah). Paradoksi ini menghadirkan sejumlah problem dalam melakukan interpretasi ( $t a^{\prime}$ will) terhadap nash Al-Qur'an.

Nalar yang dominan dan berkuasa menggunakan paradigma Bedouin dan wataknya yang keras dan kasar. Proses-proses lain banyak yang tidak diungkap oleh Al-Jabiri, namun kita temukan pada karya lain. Dalam 'Fajru al-Islam' karya Ahmad Amin misalnya menyebutkan:" dan ketika anda menyelidiki bahasa arab dan sastra arab pada masa itu, anda akan memastikannya sebagai produk dari karakterisrik kehidupan pada masa itu dan deskripsi yang membenarkan lingkungan sosiologis pada masa itu. Sehingga kafasitas kandungan makna di dalamnya terbatas pada deskripsi kehidupan Bedouin, tidak luwes dan cermat. ${ }^{20}$ Ketelitian atau kecermatan disini apabila bahasa menjadi faktor positif dalam berpikir. Akan tetapi ia membutuhkan kemampuan untuk melihat universalitas (al-nazar al-kulli) artinya membutuhkan visi universal yang konstruksional yang agung seperti Allah, al-yaum al-akhir dan sunan al-kaun dan pencermatan pada ayati Allah dan lainnya.

Berdasarkan uraian di atas, kontradiksi-kontradiksi (tanâqudh) antara nalar fikih dan nash Al-Qur'an bersemayam pada struktur bukan pada kontent. Ini dilihat dari sisi ketergantungan kita dalam memahami nash-nash Al-Qur'an pada bahasa kaum Bedouin. Padahal karakteristik bahasa Tuhan yang digunakan di dalam Al-Qur'an dengan basa Bedouin dalam bahasa komunikasi, prosa dan puisi mereka sangat berbeda, bahkan dari visi kosmopolitannya pun juga jauh berbeda.

Kontradiski-kontradiski tersebut akan jauh lebih jelas ketika kita menyimak sabda Nabi yang menolak para sahabat yang kembali kepada kehidupan era badawah (nomadisme). Dalam salah satu hadis disebutkan: من بدا جفا (sipa tinggal di pedalaman maka perangainya keras). Demikian pula pada hadis: لا يجوز شهادة بدوي على صاحب قرية (orang yang hidup di pedalaman tidak boleh menjadi saksi atas perkara penduduk kota). ${ }^{21}$ Kedua sabda Nabi

20 Amin, Fajru al-Islam; Muhammad Âbid al-Jâbirî, Fikr Ibnu Khaldun. Al-Ashabiyah wa ad-Daulah Ma'alim Nazhariyah Khladuniyah fi At-Tarikh al-Islami, vol. 1 (Beirut: Markaz Dirâsât al-Wihdah al'Arabiyah, 1994); Muhammad Âbid al-Jâbirî, Fikr Ibnu Khaldun; Al-'Ashabiyah wa ad-Daulah; Ma'âlim Nadzariyah Khaldûniyah fî at-Târikh al-Islâmî, vol. 5 (Beirut: Markaz Dirâsât al-Wihdah al-'Arabiyah, 1992).

21 Jabir, , al-Islam Baina al-Badawah wa al-Hadharah, Beirut: Dar al-Kutub Al-'Ilmiyah, 2002., hlm 27; al-Jâbirî, Isykaliyah al-Fikr al-'Arabi al-Mu'ashir; Muhammad Âbid al-Jâbirî, Isykâliyât al-Fikr al-'Arabî al- 
ini sejalan dengan firman Allah SWT dalam Surat al-Taubah ayat 97:

$$
\text { الأعر اب أثد كفر ا ونفاقا وأجدر ألا يعلموا حدود ما أنزل الله على رسوله والله عليم حكيم }
$$

“Orang-orang Arab pedesaan lebih condong bersikap kufur dan munafik, dan lebih pantas untuk tidak tahu batas-batas hukum yang diturunkan Allah kepada RasulNya. Allah Maha Mengetahui lagi Maha Bijaksana"22

Dapat kita pahami dari pesan ayat tersebut bahwa Al-Qur'an menolak al-badawah atau Bedouin bukan karena status sosial mereka, melainkan karena ia sebagai komunitas yang mengekspresikan struktur berpikir dan moral. Pemikiran mereka bersemayam pada karakter asyaddu kufran. Sedangkan akhlak mereka bermental nifaq. Baik asyaddu kufran dan nifaq terbawa dalam bahasa Bedouin (badawiyah).

Ditambahkan lagi, berpindahnya kekerasan kaum badawah (beduinism) kepada metode formulasi hukum syariah seperti hukuman rajam, potong tangan, qishas tanpa pemaafan. Semua ini bertentangan dengan logika syariah yang bercirikan rahmah dan takhfif (ringan dan santun). Pun kalau hukuman-hukuman yang kontradiktif ini muncul, maka setidaknya tidak perlu digeneralisasi, sambil melakukan penyelidikan ulang pada bahasa yang dipahami oleh para faqih dalam nash Al-Qur'an yang terkait dengan hukuman tersebut.

\section{Krisis Nalar Fikih Epistemologi Hamadian}

Sebagai pengusung mazhab 'alamiyah islamiyah, entreprise epistemologi menurut Haj Hamad adalah mentransformasikan pengetahuan menuju absolutisme (al-muthlaq) sehingga dapat ditentukan universalitasnya. Haj Hamad berangkat dari paradok yang ia temukan melalui perbandingan antara nash Al-Qur'an yang mutlak dan turas kodifikasi historis yang nisbi. Menurut Haj Hamad terdapat kontradiksi antara epistemologi terbuka dan universalitas nash Al-Qur'an yang berpijak pada al-istî'iab wa tajâwuz dangan sistem kodifikasi yang tertutup. ${ }^{23}$

Mu'âshir (Beirut: Markaz Dirâsât al-Wihdah al-'Arabiyah, 1989).

22 Zaini Dahlan, Qur'an karim dan terjemahan artinya, (Yogyakarta: UII Press, 1999), hlm 356-357.

23 Abû al-Qâsim Hâj Hamad, Ibistimûlûî̀yat al-Ma'rifah al-Kaunîyah: Islâmîyat al-Ma'rifah wa al- 
Dimensi epistemologis Haj Hamad ini kemudian menetapkan sejumlah langkah metodologis yang secara garis besar dapat dibagi menjadi dua:

Pertama, dekonstruski terhadap turas dan mengembalikannya kepada sistem keilmuannya yang historis.

Kedua, memposisikan kembali Al-Qur'an pada kemutlakannya dengan cara mengungkap sistem metodologisnya.

Dari dua langkah tersebut, dilakukan pembebasan terhadap Al-Qur'an dari dua alienasi: yaitu alienasi positivistik dan alienasi teologis. Alienasi positivistik menafikan al-gaib dan mereduksi manusia dalam dialektika alam dan al-insan, dan meremehkan al-gaib sebagai hakikat wujud yang sesungguhnya. Sedangkan alienasi teologis memahami al-gaib dalam batas kategori-kategori metafisis (maqulat metafiziqiyah) mengaleniasi manusia dan alam. Bagi Haj Hamad, justru al-gaib berinteraksi dengan absolutisme-absolutisme wujud yang lain, yaitu alam dan manusia dengan logika mediasi dialektis yang menafikan fenomena alienasi-alienasi yang dilakukan oleh positivistik mapun teologistik. Hal ini dilakukan dengan melakukan kombinasi antara dua model pembacaan yaitu kombinasi secara utuh dan komprehensif antara Al-Qur'an dan temuan-temuan ilmu pengetahuan modern. ${ }^{24}$

\section{Determinasi Al-Qur'an}

Terdapat dua hal terpenting yang ditentukan Al-Qur'an dimana dengan keduanya kebuntuan berpikir seperti disebutkan pada tantangan pertama dan kedua di atas dapat dijawab. Al-Qur'an membedakan antara dan antara النسبي dengan الثِير dan المنهاج. Menurut Haj Hamad, Al-Qur'an menegaskan bahwa semua tasyri' adalah nisbi mengambil dari kondisi realitas sosial dan historis dan karakteristik-karakteristiknya. Hal ini disebutkan di dalam ayat: لكل جعلنا ـ منكم - شِرعة ومنهاجا Allah SWT tidak mengatakan: لكل جعلنا" شِرعة ومنهاجا"yang kemudian permasalahan menjadi mutlak. Allah juga tidak mengatakan: لكل جعلنا" شِيرعة ومنهاجا"yang

Minhaj, vol. 1 (Beirut: Dâr al-Sâq1̂, 2014), hlm 254; Abû al-Qâsim Hâj Hamad, al-Fikrîyah wa al-Hadârîyah fi al-wâqi' al-'Arabî al-Râhin (Beirut: Dâr al-Sâqî, 2012M).

24 Abû al-Qâsim Hâj Hamad, Minhajîyat al-Qur'ân al-Ma'rifíyah Aslamat falsafat al-'ulum al-tabi'iyah wa al-insaniyah, vol. 1 (Beirut: Dâr al-Sâqî, 2003). Haj Hamad telah berupaya memposisikan kembali konsep al-jam'u baina al-qirâatain (integrasi dua model pembacaan) yang selama ini dipahami secara keliru oleh para peneliti IIIT. Sehubungan dengan ini Haj Hamad menulis karya khusus yang berjudul Minhajîyat al-Qur'ân al-Ma'rifíyah Aslamat falsafat al-'ulum al-tabi'iyah wa al-insaniyah.. 
menjadikan permasalahan menjadi mutlak pula. Akan tetapi Allah mengatakan: لكل جعلنا" شِرعة ومنهاجا . Di sini Allah mengembalikan sumber tasyri' kepada pengetahuan Tuhan terhadap realitas dalam arti bahwa al-muthlaq diturunka menjadi al-nisbi.

Karena itu Allah mengkorelasikan antara syir'ah yang berarti pelaksanaan-pelaksanaan (tathbiqat) dan al-minhaj yang berarti pembatasan (limitasi) karakteristik orientasi-orientasinya dan asas-asas eksperimen dan kaidahkaidahnya. Syir'ah berkorelasi dengan al-minhaj. Dengan adanya perbedaan al-minhaj maka berbeda pula al-syir'ah, dan masing-masing dari keduanya 'minkum' karena Allah mengatakan :

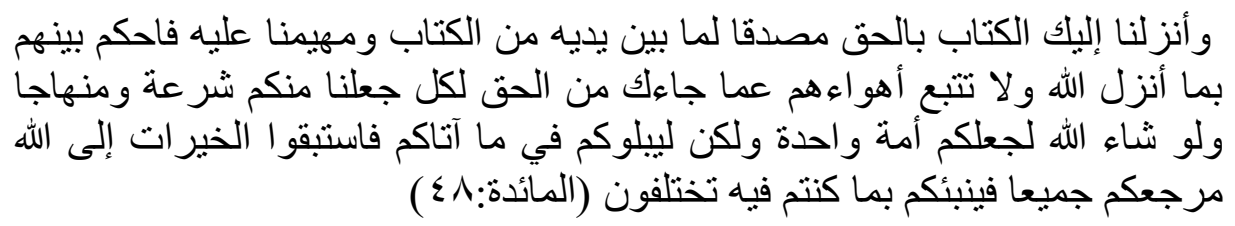

"Kami turunkan kepada kitab dengan haq yang menguatkan kitab yang datang terdahulu dan yang menjaga dasar-dasar ajarannya. Karena itu berhukumlah untuk mereka menurut yang diturunkan Allah, dan jangan mengikuti kehendak mereka yang menyimpang dari kebenaran yang datang kepadamu. Masing-masing dari kamu ada tatanan dan jalan yang terang. Sekiranya Allah menghendaki pasti Allah membikin kamu satu umat saja, tetapi Allah ingin menguji kamu semua tentang pelaksanaan isi kitab yang datang kepadamu. Oleh karena itu, berlomba-lombalah dalam kebaikan, kepada Allah jua tempat kembalimu semua. Ia akan memberitahukan hal yang kamu perselisihkan"25

\section{Contoh Pelaksanaan (misal tathbiqi)}

Kesatuan agama dan perbedaan syir'ah dan minhaj dari Adam sampai kepada Israil dan muslim.

Agama di sisi Allah, sesungguhnya adalah satu yaitu Islam sejak Adam As. sampai hari kiamat. Akan tetapi al-minhaj berbeda dengan perbedaan situasi dan kondisi.

25 Dahlan, Qur'an karim dan terjemahan artinya, hlm 202-203; Abû al-Qâsim Hâj Hamad, al-Qur'ân wa al-Mutagaiyirât al-Ijtimâ'iyah wa al-Tarikhiyah, vol. 1 (Beirut: Dâr al-Sâqî, 2012M). 
Titah Allah (khitab Allah) kepada Adam As. berada dalam frame atau ruang lingkup keluarga (Q.S.Al-Baqaroh:35). Mengikuti minhaj-nya adalah syir'ah-nya. Sedangkan titah Allah kepada kaum Bani Israil sejalan dengan minhaj mereka yaitu khitab dalam ruang lingkup kesukuan atau kabilah (qobali). Dalam fase ini syir'ah yang berlaku sangat keras dan sadis (ishr wa aglâl). Bersamaan dengan ini, mukjizat yang diterima oleh para nabi sejak nabi Musa As. dan nabi-nabi yang datang pasca Musa As. berupa mukjizat hissiyah atau kemukjizatan indrawi berupa anugerah yang riil. Dalam era ini intervensi Tuhan bersifat langsung yang disebut oleh Haj Hamad dengan hakimîyyah ilaâhîyah. Oleh karena itu solusi terhadap berbagai problem yang menimpa umat Yahudi diselesaikan langsung oleh Allah misalnya krisis air minum Allah memerintahkan Musa untuk memukul batu sehingga mengeluarkan dua belas mata air. Demikian pula krisis makanan dan kepemimpinan, Allah mendatangkan makanan bergizi berupa al-manna dan al-salwa, dan juga mengutus Tholut sebagai jawaban atas permintaan umat Yahudi untuk mengalahkan Jalut.

Adapun minhaj Islami Qurani berbeda dengan minhaj Yahudi Taurati. Titah atau khitab Tuhan kepada umat Islam bersifat global atau internasional ('alamî) menggantikan khitab kepada Yahudi yang bersifat kekabilahan. Demikian pula hukum taurati yang berlaku kepada mereka yang bercirikan al-isr dan al-aglal (sadis) diganti dengan hukum atau syir'ah takhfif dan rahmah (ringan dan santun). Kemukjizatan yang bersifat hissiyah kepada nabi Musa di ganti dengan mukjizat giru hissiyah.

Intervensi Tuhan yang bersifat langsung kepada umat Yahudi yang disebut Haj Hamad dengan Hakimîyah ilâhiyyah diganti dengan hakimîyyah al-kitab. Hamad juga menyebutnya dengan hakimîyyah basyariyah yaitu ada kebebasan manusia dalam menetapkan hukum berdasarkan Al-Qur'an dengan mengembangkan metode yang seirama dengan perkembangan zaman. Keberadaan Al-Qur'an jauh lebih penting dari kenabian. Pernyataan ini dikemukakan Haj Hamad mengacu kepada Q.S.Al-Waqi' ah ayat 75-81. Allah berfirman: 


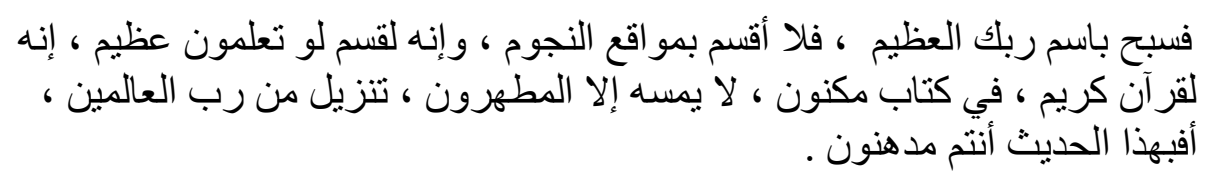

"Maka, bertasbihlah dengan nama Tuhanmu Yang Maha Agung, dan, Kami bersumpah dengan tempat jatuhnya bintang. Itu adalah sumpah yang besar kalau kamu sadari. Bahwa Al Qur'an sungguh bacaan yang sangat mulia. Dalam sebuah kitab yang rapi tersimpan, tak dapat menyentuhnya ${ }^{26}$ kecuali mereka yang suci". ${ }^{27}$

Ayat ayat-ayat tersebut dan sejumlah ayat di tempat lain mencerminkan bahwa Al-Qur'an jauh lebih penting daripada kenabian. Al-qudwah atau keteladanan kepada Nabi digantikan posisinya oleh al-minhaj Al-qur'ani. Lebih jauh menurut Haj Hamad, Al-Qur'an memiliki sifat al-Karim, al-'Azim dan al-Maknun. Makna-makna yang terpendam hanya dapat diungkap dengan al-minhaj oleh orang-orang yang suci. Oleh karena itu kata Hamad Nabi tidak dalam posisi menafsirkan Al-Qur'an, dan Al-Qur'an pun turun tanpa asbab al-nuzul. Doktrin bahwa Nabi menafsirkan Al-Qur'an dan turunnya suatu ayat karena latar belakang tertentu sama artinya dengan membatasi kemutlakan Al-Qur'an. Dan ini mustahil terjadi.

Selain itu Hamad berkeyakinan tata letak surat ayat bahkan kata demi kata di dalam Al-Qur'an bersifat taufiqi yaitu perintah langsung dari Allah. Jika satu kata atau ayat dipindahkan posisinya dari tempat semula akan merusak makna persis seperti posisi bintang atau plenet yang bersifat permanen. Jika terjadi perubahan akan mengakibatkan goncangan hebat. Oleh karena itu, tegas Haj Hamad, Al-Qur'an tidak membutuhkan tafsir atau ta'wil (interpretasi) yang menjadi porsi umat Islam pada globalisasi Islam Pertama, melainkan tahlil (analisis) mengingat Al-Qur'an secara keseluruhan merupakan satu kesatuan organis yang tidak dapat dipisahkan. Suatu tahlil terhadap Al-Qur'an berbasis pada hakimîyah basyarîyah yaitu otoritas mutlak manusia dengan menggunakan elemen konstitutifnya (berupa

26 Hamad, Ibistimûlûjîyat al-Ma'rifah al-Kaunîyah: Islâmîyat al-Ma'rifah wa al-Minhaj. Haj Hamad mengartikan al-massu dengan 'memahami'. Sedangkan menyentuh bersifat hissi yang dalam bahasa AlQur'an disebut al-lams. Berbeda dengan al-massu yang bersifat maknawi. Ini tidak lepas dari paradigma interpretasi Hamad yang tidak mengakui adanya makna sinonim dan makna ganda di dalam Al-Qur'an. Semua 'kata' di dalam Al-Qur'an bersifat terminologis yang hanya mengandung satu makna.

27 Dahlan, Qur'an karim dan terjemahan artinya, hlm 973. 
al-sam'u, al-bashar dan alfuad) dalam menentukan kandungan Al-Qur'an yang bersifat al-maknun, al-Karim dan al-'Azim.

Untuk memperkuat hirarki al-hakimîyah, Hamad membagi perbuatan Tuhan menjadi tiga tingkatan. Masing-masing tingkatan berimplikasi pada corak hukum. Surat Yâsîn ayat 82 yang menyatakan: إنما أمره إذا أراد شيئا أن يقول له كن فيكون (Sungguh bila Ia menghendaki terjadinya sesuatu, cukuplah Ia perintahkan: “Jadilah!" dan terjadilah ia).

Dari kata al-amr mencerminkan bahwa perbuatan Tuhan (al-fi'l al-ilahi) berada pada level 'alamul amri. Di sini tidak seorang yang mengetahui rahasia perbuatan Tuhan. Sedangkan dari kata arada mencerminkan 'alamul irâdah, artinya Allah berbuat sesuatu berdasarkan interaksi melalui utusanNya. Hal ini terjadi pada kenabian Taurati dan relevan dengan hakimîyah ilahîyah. Sedang kata syaian mencerminkan perbuatan Tuhan pada 'alam al-masyîah. Allah akan menetapkan sesuatu berdasarkan hubungan kausalitas yang tercermin dalam dialektika manusia dengan alam dan Tuhan. Bentuk perbuatan Tuhan dalam konteks 'alam al-masyiah inilah yang terjadi pada umat Muhammad. Di sinilah letak singkronnya konsep hakimîyah basyarîyah dengan 'alamul masyiah yang harus dipahami dengan melakukan al-jam'u baina al-qirâtain.

\section{EPISTEMOLOGI HAMADIAN DAN NALAR FIKIH KONTEMPORER}

Kehadiran epistemologi Haj Hamad tampaknya ingin memposisikan manusia pada absolutismenya yang telah direduksi oleh doktrin positivistik dan teologis. Yang relevan dengan kajian kita saat ini adalah yang terakhir yaitu teologistik karena di dalamnya terkandung nalar fikih. Di sini Haj Hamad mengungkap sekaligus memperkenalkan paradigma baru untuk memahami paradok-paradok fikih baik itu mengarah pada manusia maupun dalam berinteraksi dengan nash Al-Qur'an. Di sini muncul pertanyaan "di manakah tempat bersemayamnya sumber krisis paradoksial dalam krisis nalar fikih?

Untuk menjawab pertanyaan tersebut, sangat baik kita kembali kepada karya monumentalnya 'al-'Alamiyyah al-Islamiyyah al-Saniyyah' yang menjelaskan metode-metode konstruksi keilmuannya: "aspek pertama khusus mengembalikan pembacaan nash-nash yang berhubungan dengan tasyri'at 
islamiyyah dan metode memahami sunnah-sunnah ${ }^{28}$ Nabi yang sahih..." 29 Hal ini berarti proyek Haj Hamad mengarah menuju proses tasyri' dan mengkorelasikannya dengan Sunnah Nabi. Ini ternyata mampu menjelaskan krisis nalar fikih yang dapat kita sarikan dalam dua unsur asasi yaitu karakter (tahabi'ah) dan sumber (al-mashdar).

Unsur krisis pada thabi'ah, adalah karakter penetapan hukum (thabi'ah tasyri'iyah) yang men-alineasi manusia. Di sini Haj Hamad menetapkan kurang lebih tigabelas alineasi di antaranya berkaitan dengan kebebasan manusia, pemunculan inferioritas perempuan yang dihadapkan dengan superioritas kaum laki-laki seperti mengaleniasi perempuan dari aktifitas peradaban dan pekerjaan-pekerjaan di sektor publik, demikian pula hukumanhukuman yang sadis (al-hudud al-qosiyah) seperti hukuman dera, hukuman potong tangan dan lain sebaginya yang masuk dalam kategori alienasi atau perampasan.

Sedangkan dari sisi al-mashdar atau sumber, menurut Haj Hamad banyak berasal dari israiliyat, bukan dari nash-nash Al-Qur'an. Akibatnya nashnash tasyri' tidak dipahami menggunakan logika syir'atu al-takhfif wa alrahmah yang mencari ciri hukum Islam, melainkan dengan logika al-ishru wa al-aglal yang bernuansa Taurati atau Talmudi.

Sumber atau al-mashdar menjadi titik tolak dan menjadi asas keberadaan paradok nalar fikih. Sehubungan dengan ini Haj Hamad mengatakan:"kami telah menjelaskan keunggulan tasyri' islami yaitu (takhfif dan rahmah) yang berlawanan dengan tasyri'at (al-ishru wa al-aglal) Yahudi melalui penelitian dan penyelidikan pada sistem, formula, metode dan karakter hubungan masing-masing agama Allah SWT"30. Sesungguhnya Bani Israil mengunakan syir'ah al-ishru wa al-aglal berdampingan dengan anugerah Tuhan

28 Hamad, al-Muhaddadat al-Qur'aniyyah Li-Shiyagati al-Nash al-Tasyri'i baina al-Muthlaq wa alNisbi wa baina al-Syir'ah wa al-Minhaj. Haj Hamad menyatakan hampir keseluruhan hadis masuk dalam kategori al-manhul atau dipalsukan oleh israiliyat. Nabi sejak awal melarang penulisan hadis karena suatu kekhawatiran jangan sampai umat ini komitmen pada "hadis atau sunnah" dengan meninggalkan AlQur'an. Sehingga akan melahirkan 'Islam Sunnah' bukan Islam Qur'ani. Fenomena ini pernah terjadi di kalangan Yahudi yang komitmen pada syariah Talmudi dengan gerakan takfiri mereka, bukan syariah Taurati. Hamad juga mengatakan "gerakan takfiri" adalah karakter Yahudi, bukan berasal dari Islam.

29 Hamad, al-'Âlamîyah al-Islâmîyah al-Sânîyah: Jadalîyat al-Gaib wa al-Insân wa al-Tabî'ah, Taqdîm wa Murâja'ah Muhammad al-'Ânî, hlm 52.

30 Hamad, Ibistimûlûjîyat al-Ma'rifah al-Kaunîyah: Islâmîyat al-Ma'rifah wa al-Minhaj, 1:hlm 52; Abû al-Qâsim Hâj Hamad, Juzur al-Ma'zaq al-Uşûlî, vol. 1 (Beirut: Dâr al-Sâqî, 2012M); Abû al-Qâsim Hâj Hamad, Tasyri'ât al-'âilah fi al-Islâm, vol. 1 (Beirut: Dâr al-Sâqî, 2012M). 
"al-'atho' al-Ilahi" dan kemu'jizatan fisikis "al-khawariq al-rabbaniyah". Sementara fase atau marhalah Islam tidak dikarakterisasikan dengan al-'atho' al-khoriq, melainkan dengan Al-Qur'an al-Karim. Karena ini syariatnya berupa takhfif dan rahmah.

Argumen yang dikemukakan Haj Hamad adalah penodaan yang dilakukan kaum Israili terhadap banyak hadis sehingga memunculkan perten"tangan (tanaqudh). Mislanya, sabda Nabi : "كلكم راع وكلكم مسئول عن رعيتها permaslahan yang muncul di sini adalah kata ra'in bertentangan dengan ayat Al-Qur'an yang menyebutkan kata 'râ'ina dalam Surat al-Baqarah

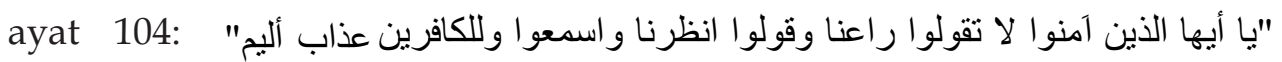
(Hai orang-orang yang beriman, jangan gunakan kata "râ'inâ kepada rasul, tetapi pergunakanlah kata "unzurnâ" dan dengarkan baik-baik apa kata rasul, dan bagi mereka yang ingkar mendapat siksa yang pedih). Demikian pula dalam Surat al-Nisa ayat 46: "

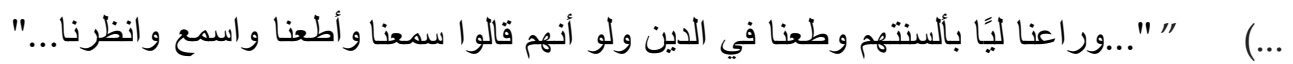
Mereka mengatakan, "Râ'inâ" (dengan maksud ejekan) dan memutarbalikkan makna ucapannya serta mencerca agama. Sekiranya mereka berikrar, "Sekiranya mereka berikrar, "Kami mendengar dan kami patuh, dengar dan perhatikanlah kami", ,...).

Haj Hamad memahami ada pertentangan (kontradiksi) yang jelas antara penolakan Al-Qur'an terhadap kata 'râ' nâ' yang dinodai oleh Yahudi dalam hadis (tentang tanggung jawab seorang pemimpin) dengan kata 'unzurnâ' yang muncul di dalam Al-Qur'an. Kata 'râ'inâ' mencederai dan menurunkan nilai-nilai kemanusiaan karena akan mengkonversi manusia menjadi gerombolan sapi atau kambing (al-qathi'). Adapaun kata 'unzurnâ' akan mengangkat dan mengagungkan nilai-nila kemanusiaan melalui al-nazar yang menunjukkan signifikasi intelektualitas (ta'aqqul) dan kecerdasan (bashirah).

Hamad menambahkan amunisi untuk memperkuat tesisnya dalam karyanya 'Epistimulujiya al-Ma'rifah al-Kauniyyah' melalui argumentasinya dengan larangan Nabi SAW dalam sahih muslim untuk tidak mengambil dari Nabi kecuali Al-Qur'an, selain Al-Qur'an harus dihapus dan tidak perlu dipelihara. Haj Hamad menginterpretasi penolakan Nabi tersebut se- 
bagai suatu larangan memproduksi kitab yang parallel dengan Al-Qur'an al-Karim, sebagaimana diperbuat Banu Israil ketika menjadikan Talmud sebagai pengganti Taurat. Hal ini nyaris terjadi pada Al-Qur'an yang akan tergantikan dengan posisi Sunnah yang notabenenya banyak dimasuki oleh israiliyat yang mengaleniasi manusia dengan logika teologis yang picik dan sempit". ${ }^{31}$

Oleh karena itu, konsep al-maqashid yang ditawarkan Haj Hamad terlihat pada permasalahan al-minhaj yang mencerminkan kelahiran baru bagi insan Arab dan muslim:"bukan kembali kepada 'an 'anât Ibn Kasir dan apa yang pasti dan tidak pasti dari hadis-hadis Rasul. Karena globalisasi Islam ke Dua dan baru bagaimanapun juga bukan pembaharuan dari globalisasi Islam Pertama. Ia adalah sejarah peradaban baru yang berkelanjutan. Globalisasi dalam kelahiran dan pembentukannya untuk pertama kali mengambil metode universal dari Al-Qur'an dengan segenap totalitarisme dan keluasannya sebagaimana kemamampuan manusia. ${ }^{32}$

Ia adalah globalisasi Islam ke Dua yang tidak akan mewarisi pemahaman dan pembumian Al-Qur'an dari globalisasi Islam Pertama, dan tidak pula akan mewarisi konsep interpretasinya. Akan tetapi menempatkan kembali aplikasi dan interpretasi esoterisme dengan konsep metode baru bagi Al-Qur'an dalam kesatuan organis dan signifikasi kosmisnya. Penempatan kembali ini datang melalui pelampauan sejarah fase Bedouin Arab yang terbelakang. ${ }^{33}$

Dari sini, maka "kearifan, perhatian dan kecermatan dalam berpikir dan perenungan terhadap al-minhaj al-qurani al-kulli mendorong kita untuk mencari maknunat Al-Qur'an, dan akan menampakkan kepada kita metode yang digunakan dalam memahami Al-Qur'an pada fase historis tertentu tidak berarti bahwa pemahaman pada waktu itu salah. Pemahaman pada waktu itu sudah sesuai dengan situasi dan kondisi sosial umat muslim. Memahami Al-Qur'an dalam karakteristik (khasaish) realitas sudah menjadi bagian muslim dalam setiap zaman. Akan tetapi yang salah adalah memper-

31 Hamad, Ibistimûlûjîyat al-Ma'rifah al-Kaunîyah: Islâmîyat al-Ma'rifah wa al-Minhaj, hlm 98-99.

32 Hamad, al-'Âlamîyah al-Islâmîyah al-Sânîyah: Jadalîyat al-Gaib wa al-Insân wa al-Tabî'ah, Taqdîm wa Murâja'ah Muhammad al-'Ân̂, hlm 334.

33 Hamad, al-'Âlamîyah al-Islâmîyah al-Sânîyah: Jadalîyat al-Gaib wa al-Insân wa al-Tabî'ah, Taqdîm wa Murâja'ah Muhammad al-'Ân̂, hlm 258. 
tahankan, mengaplikasikan atau memperaktikkan konsepsi-konsepsi terdahulu (tajribah salafiyah) pada karakteristik realitas yang berlainan. Dengan mempertimbangkan berbagai perubahan realitas historis, dan dengan keberadaan Al-Qur'an yang berkelanjutan dan abadi, maka Allah menjadikan al-minhaj sinonim dengan qudwah nabawiyah dan menjadikan waskita pada al-maknun. Tentunya ini menggunakan al-minhaj sebagai ganti pemahaman terdahulu (salafi) terhadap Al-Qur'an. ${ }^{34}$

Hamad menegaskan 'alamiyah islamiyah al-saniyah bukan risalah saniyah yang diperkenalkan oleh Mahmud Muhammad Thaha yang bercorak gnostik sebagaimana dituduhkan oleh sebagian orang. Melainkan 'alamiyah saniyah yang memiliki kontent baru bukan dari praktik-praktik salafiyah dan konsep salafi. Akan tetapi dari abstraksi metodologis qurani yang mengalahkan makna-makna yang dipraktikkan pada fase terdahulu. ${ }^{35}$

Al-minhaj menurut pandangan Haj Hamad adalah "sistem yang mengatur produk-produk pemikiran yang memiliki satu sistem" terbebasnya akal dari proses generasi subyektif terhadap pemikiran menuju penemuan sistem referensional. ${ }^{36}$ Adapun al-minhaj al-Qur'ani menurutnya ditentukan dalam tiga unsur: Ma'na al-Qur'an, Minhaj, khashaish al-'alamiyyah (karakteristik universal). ${ }^{37}$

Singkatnya dari epistemologi Haj Hamad, nalar fikih jatuh dalam krisis yang terpusat pada aleniasinya terhadap nash Al-Qur'an melalui struktur pemikiran yang dibentuk oleh fenomena israilian yang menodai sumber terutama hadis atau sunnah. Dan 'sunnah' yang bercorak israiliyat ini membentuk paradigma pemahaman. Inilah tempat yang paling berbahaya karena memahami nash-nash tasyri'i di dalam Al-Qur'an bukan atas asasasas takhfif dan rahmah, melainkan atas asas al-ishru wa al-aglal. Akibatnya terlahirlah sistem fikih yang menindas manusia, bukan membebaskannya. Yang lebih berbahaya dari itu semua melemahkan pemahaman pada

34 Hamad, al-Âlamîyah al-Islâmîyah al-Sânîyah: Jadalîyat al-Gaib wa al-Insân wa al-Tabî'ah, Taqdîm wa Murâja'ah Muhammad al-'Ân̂̀, hlm 257.

35 Hamad, al-'Âlamîyah al-Islâmîyah al-Sânîyah: Jadalîyat al-Gaib wa al-Insân wa al-Țabî'ah, Taqdîm wa Murâja'ah Muhammad al-'Ân̂̀ hlm, 257.

36 Abû al-Qâsim Hâj Hamad, Minhajîyat al-Qur'ân al-Ma'rifîyah Aslamat falsafat al-'ulum al-tabi'iyah wa al-insaniyah, vol. 1 (Beirut: Dâr al-Sâqî, 2003), hlm 22-23.

37 Hamad, al-'Âlamîyah al-Islâmîyah al-Sânîyah: Jadalîyat al-Gaib wa al-Insân wa al-Țabî'ah, Taqdîm wa Murâja'ah Muhammad al-'̂̂n̂̂, hlm 291-294. 
absolutisme Al-Qur'an (muthlaqiyat Al-Qur'an) dan membatasi jangkauan makna Al-Qur'an pada frame historis masa lampau.

\section{KESIMPULAN}

Kesimpulan yang dapat kita peroleh dari pembahasan sederhana ini termanifestasi pada nilai pembacaan epistemologis terhadap krisis nalar fikih. Karena dari sisi interpretasi, ia mampu menembus nalar fikih yang terdalam untuk mengungkap yang tersembunyi dan invisible (al-lamar'i) bagi usaha nalar musyarri' (mujtahid atau mufti). Mereka tidak melakukan pelurusan hubungan antara nash dengan realitas dan metode yang mungkin dapat digunakan untuk menyimpulkan hukum. Komposisi budaya yang membentuk nalar klasik untuk memahami nash Al-Qur'an hanya dapat diungkap dengan epistemologi. Karena ia mampu mengungkap peran-peran yang tersembunyi dalam membentuk suatu pemikiran. Dan otoritas budaya yang membentuk pemikiran ini terlihat pada nalar fikih.

Melalui tesis Abed Al-Jabiri dan Muhammad Abu al-Qasim Haj Hamad, unsur-unsur yang yang menjadi sumber krisis nalar fikih dapat diketahui dan dikontrol. Sehingga silang pendapat dalam tasyri' qurani yang lazim didukung oleh hadis atau sunnah dapat diminimalkan.

Al-Jabiri telah memperlihatkan kepada kita bagaimana dominasi paradigma Bedouin dan pengaruhya yang dibungkus dalam bahasa yang dikumpulkan dari Arab pedalaman yang tidak terbebaskan dari warisan Jahiliyah mengintervensi pemahaman umat terhadap nash Al-Qur'an.

Adapun Muhammad Abu al-Qasim Haj Hamad memperhatikan dan mewaspadai kemunculan syir'atu al-ishru wa al-aglal dan masuknya ke dalam syariah islamiyah yang rahmah dan takhfif dengan cara melakukan penyusupan melalui sunnah manhulah (sunnah yang dipalsukan).

Selain itu, relatifitas tasyri' al-munazzal menurut al-Jabiri dan Haj Hamad mengikuti situasi dan kondisi historis dan kondisi-kondisi sosial yang beragam. Hukuman seperti potong tangan dan hukuman rajam adalah berlaku pada masa historis itu karena kesejalanannya dengan situasi-situasi sosial ketika itu, kata al-Jabiri. Dimana komunitas masyarakat Bedouin 
primitif yang nomaden tidak memiliki penjara dan jendala. Mereka hanya memiliki kemah. Maka bagaimana mungkin menjobloskan pencuri ke dalam penjara. Bagaimana cara melindungi harta. Maka diperlukan hukuman yang membedakan pencuri agar masyarakat bisa menghindarinya. Berbeda dengan Haj Hamad, hukuman yang tergolong sadis tersebut merupakan hukuman yang termaktub di dalam Taurat, sehingga pemberlakukannya sudah dihapus oleh Al-Qur'an, sebagaimana ditegaskan oleh Haj Hamad. ${ }^{38}$

Pada ujung akhir tulisan ini, Al-Qur'an menurut pandangan epistemologi Jabirian dan Hamadian menjelaskan relatifitas tasyri' yang dikorelasikan dengan situasi dan kondisi sosial. Hal ini sesuai dengan pernyataan Al-Qur'an: ) "لكل جعلنامنكم شِرعة ومنهاجا" Masing-masing dari kamu ada tatanan dan jalan yang terang). ${ }^{39}$ Dengan demikian, hanya prinsip hukuman dan pembalasan (mabda' al-'uqubah wa al-jaza') yang berada pada wilayah permanen. Adapun bentuk-bentuk pengaplikasian dari prinsip ini diserahkan sepenuhnya pada masa sesuai dengan situasi, kondisi, tradisi dan nilainilai. Dengan demikian, rincian aplikasi dan implementasinya diserahkan kepada kulliyat al-minhaj. ${ }^{40}$ Dengan ini, Al-Qur'an mengakomodasi perubahan-perubahan faktual di masyarakat, dan bersifat abadi seperti kehendak Allah sholih likulli zaman wa makan. ${ }^{41}$

Dan bagian yang paling akhir dari tulisan ini terdapat dua hal yang layak mendapat perhatian. Nalar fikih membutuhkan filsafat ilmu, filsafat ilmu yang terbarukan dan diperkaya dengan konsep-konsep keilmuan Islam. Hanya dengan memahami filsafat ilmu, atau epistemologi meminjam istilah Haj Hamad filsafat fikih dapat dikembangkan. Kontens filsafat tasyri' yang ada sekarang perlu dilengkapi dengan produk-produk keilmuan metode fikih kontemporer. Tanpa itu fikih akan selamanya mengidap penyakit alqushur al-zati penyakit lumpuh yang membuat tidak bisa bergerak.

\section{DAFTAR PUSTAKA}

38 Hamad, hlm 291-94.

39 Dahlan, Qur'an karim dan terjemahan artinya,.

40 Hamad, al-'Âlamîyah al-Islâmîyah al-Sânîyah: Jadalîyat al-Gaib wa al-Insân wa al-Tabî'ah, Taqdîm wa Murâja'ah Muhammad al-'Ân̂̂, hlm 249.

41 Hamad, Juzur al-Ma'zaq al-Uşûlî, 1:hlm 378-379; Muhammad Âbid al-Jâbirî, Wijhah Nadzr Nahw I'adah Bina Qadlaya al-Fikr al-Mu'ashir, vol. 1 (Beirut: Markaz Dirâsât al-Wihdah al-'Arabiyah, 1992). 
Abdurrazak Al Khani, Ahmad. Mukhtashar al bidayah wa an-nihayah sejarah awal mula penciptaan, kisah para Nabi, kisah umat-umat terdahulu, sejarah Nabi SAW dan Khulafa'Rasyidun, daulah Umawiyah dan Abasiyah, hingga peristiwa tahun 768H. Jakarta: Pustakaazzam, 2013. Amin, Ahmad. Fajru al-Islam. Beirut: Dar al-Kitab al-'Arabi, 1969.

Dahlan, Zaini. Qur'an karim dan terjemahan artinya,. Yogyakarta: UII Press, 1999.

Firdausy, Muhammad Anwar. "Filsafat Mohammad Abid Al Jabiri dan Relevansinya dalam Pemikiran Islam Kontemporer," t.t.

Hamad, Abû al-Qâsim Hâj. al-'Âlamîyah al-Islâmîyah al-Sânîyah: Jadalîyat al-Gaib wa al-Insân wa al-T,Tabî’ah, Taqdîm wa Murâja'ah Muhammad al-'Ânî,. 3 vol. Beirut: Dâr al-Sâqî, 2012M.

- - - al-Fikrîyah wa al-Hadârîyah fi al-wâqi' al-'Arabî al-Râhin. Beirut: Dâr al-Sâqî, 2012M.

- - - . al-Muhaddadat al-Qur' aniyyah Li-Shiyagati al-Nash al-Tasyri'i baina al-Muthlaq wa al-Nisbi wa baina al-Syir'ah wa al-Minhaj. Vol. 1. Beirut: Dâr al-Sâqî, 1999.

- - - al-Qur'ân wa al-Mutagaiyirât al-Ijtimâ'iyah wa al-Tarikhiyah. Vol. 1. Beirut: Dâr al-Sâqî, 2012M.

- - - Ibistimûlûjîyat al-Ma' rifah al-Kaunîyah: Islâmîyat al-Ma'rifah wa alMinhaj. Vol. 1. Beirut: Dâr al-Sâqî, 2014.

- - - Juzur al-Ma'zaq al-Uşûlî. Vol. 1. Beirut: Dâr al-Sâqî, 2012M.

- - - Minhajîyat al-Qur'ân al-Ma'rifîyah Aslamat falsafat al-'ulum altabi'iyah wa al-insaniyah. Vol. 1. Beirut: Dâr al-Sâqî, 2003.

- - - Tasyri'ât al-'âilah fi al-Islâm. Vol. 1. Beirut: Dâr al-Sâqî, 2012M.

Jabir, Habib Qasim. , al-Islam Baina al-Badawah wa al-Hadharah, Beirut:

Dar al-Kutub Al-‘Ilmiyah, 2002. Beirut: Dar al-Kutub Al-'Ilmiyah, 2002. Jâbirî, Muhammad Âbid al-. Al-'Aql asy-Syiyâsî al-Arabî, Muhaddadâtuhu wa Tajalliyâtuhu. Vol. 2. Beirut: Markaz Dirâsât al-Wihdah al-'Arabiyah, 1991. - - - . At-Turats wa al-Hadatsah: Dirasah wa Munaqasyah. Vol. 1. Beirut: Markaz Dirâsât al-Wihdah al-'Arabiyah, 1991.

- - - Bunyah al-'Aql al-'Arabî, Dirâsah Tahlîliyah Naqdiyah li Nadzm al-Ma'rifah al-'Arabiyah. Vol. 3. Beirut: Markaz Dirâsât al-Wihdah al'Arabiyah, 1990. 
- - - . Fikr Ibnu Khaldun; Al-'Ashabiyah wa ad-Daulah; Ma'âlim Nadzariyah Khaldûniyah fî at-Târikh al-Islâmî. Vol. 5. Beirut: Markaz Dirâsât al-Wihdah al-'Arabiyah, 1992.

- - - . Fikr Ibnu Khaldun. Al-Ashabiyah wa ad-Daulah Ma'alim Nazhariyah Khladuniyah fi At-Tarikh al-Islami. Vol. 1. Beirut: Markaz Dirâsât al-Wihdah al-'Arabiyah, 1994.

- - - . Hafriyât fî adz-Zhâkirah min Ba'id. Beirut: Markaz Dirâsât al-Wihdah al-'Arabiyah, 1997.

- - - Isykaliyah al-Fikr al-'Arabi al-Mu'ashir. Vol. 1. Beirut: Markaz Dirâsât al-Wihdah al-'Arabiyah, 1994.

- - - Isykâliyât al-Fikr al-'Arabî al-Mu'âshir. Beirut: Markaz Dirâsât alWihdah al-'Arabiyah, 1989.

- - - . Madkhal Ila Falsafah al-‘Ulum. Vol. 1. Beirut: Markaz Dirâsât alWihdah al-'Arabiyah, 1988.

- - - Wijhah Nadzr Nahw I'adah Bina Qadlaya al-Fikr al-Mu'ashir. Vol. 1. Beirut: Markaz Dirâsât al-Wihdah al-'Arabiyah, 1992.

Miles, Matthew B., dan A. Michael Huberman. Analisis Data Kualitatif: Buku Sumber Tentang Metode-metode Baru. UI Press, 2009. https:// openlibrary.telkomuniversity.ac.id/pustaka/9207/analisis-data-kualitatif-buku-sumber-tentang-metode-metode-baru.html.

Rizal, Syamsul. "Epistemologi Filsafat Islam dalam Kerangka Pemikiran Abid Al-Jabiri." At-Tafkir 1, no. 1 (2014): 100 - 130-100 - 130.

Rofiq, Muhamad. "Arab Political Reasoning: Muhammad Abid al-Jabiri's Contribution for Understanding Crisis of Politics in the Arab World." Indonesian Journal of Islam and Muslim Societies 7, no. 1 (1 Juni 2017): 55-76. https:/ / doi.org/10.18326/ijims.v7i1.55-76.

Wahyudi, Wahyudi, dan Muhammad Zaini. "Characteristics and Paradigm of Sufi Tafsīr in 'Abid Al-Jabiri Epistemology Perspective." Kalam 12, no. 1 (3 Juli 2018): 159-78. https:/ / doi.org/10.24042/klm.v12i1.2152.

Wirianto, Dicky. "Wacana Rekonstruksi Turas (Tradisi) Arab Menurut Muhammad Abed al-Jabiri Dan Hasan Hanafi," t.t.

Yusuf, A. Muri. Metode penelitian : kuantitatif, kualitatif, dan penelitian gabungan. Kencana, 2015. 